\title{
Changes in Selected Properties of Wood Caused by Gamma Radiation
}

\author{
Radovan Despot ${ }^{1}$, Marin Hasan ${ }^{1}$, Andreas Otto Rapp ${ }^{2}$, Christian Brischke², \\ Miha Humar ${ }^{3}$, Christian Robert Welzbacher ${ }^{2}$ and Dušan Ražem ${ }^{4}$ \\ ${ }^{1}$ Faculty of Forestry, University of Zagreb, \\ ${ }^{2}$ Leibniz Universität Hannover, Faculty of Architecture \\ and Landscape Sciences, Hannover, \\ ${ }^{3}$ Biotechnical Faculty, University of Ljubljana, \\ ${ }^{4}$ Ruđer Bošković Institute, Zagreb, \\ 1,4 Croatia \\ ${ }^{2}$ Germany \\ ${ }^{3}$ Slovenia
}

\section{Introduction}

Wood as a natural organic material is susceptible to biodeterioration by insects, fungi, and bacteria. There is almost no wooden artefact or old wooden element, which is not infected and not damaged, at least partly, by wood-destroying organisms. As ancient wood and wooden artefacts are invaluable, their appropriate restoration is of particular importance. The first step in restoration is the detection and quantification of wood pests and decay and accordingly, under certain conditions, the disinfestation of ancient wood and old wooden artefacts could be needed.

Besides disinfestation prior to restoration, sterilization of wood is applied for testing the resistance of wood and wooden products against wood-destroying organisms. For both purposes, restoration and resistance testing, gamma radiation is considered as a suitable decontamination method.

\section{Gamma radiation as a sterilisation method}

Gamma radiation, as a high energy, ionising electromagnetic radiation, easily penetrates through wooden objects. It is known to be very effective in the context of disinfestation of wooden artefacts (Unger et al., 2001; Katušin-Ražem et al., 2009; Fairand and Ražem, 2010) but also for wood sterilisation (Sharman and Smith, 1970; Shuler, 1971; Freitag and Morrell, 1998; Pratt et al., 1999; Severiano et al., 2010). In contrary to alpha and beta rays, which penetrate only very thin layers, gamma radiation fully penetrates wooden objects (Fengel and Wegener, 1989; Tišler and Medved, 1997). The energy-rich gamma rays modify molecular structures and lead to unexpected function of living cells or to their death. 


\subsection{Doses of gamma radiation necessary for wood sterilisation}

According to Kunstadt (1998), insects do not withstand doses between 0.7 and $1.3 \mathrm{kGy}$, while elimination of fungi requires significantly higher doses. Unger et al. (2001) mentioned doses between 0.25 and $3 \mathrm{kGy}$ to be adequate for extermination of wood-destroying insects, depending on species and developmental stage. Extermination of wood decay fungi in wood usually requires higher doses, ranging from 2 to $18 \mathrm{kGy}$ depending on the fungus species. Mycelium of the fungus Serpula lacrymans can be killed off with $2-3 \mathrm{kGy}$, but it can be reduced to $0.5 \mathrm{kGy}$ if the temperature rises to $50^{\circ} \mathrm{C}$. Unger et al. (2001) also stated that the bacteria elimination requires doses of 3 - $15 \mathrm{kGy}$. Lester et al. (2000) sterilised New Zealand soft woods including radiata pine (Pinus radiata) against Huhu beetle larvae (Prionoplus reticularis) and concluded that doses between 2.5 and $3.7 \mathrm{kGy}$ are enough to control wood destroying insects and that moisture content of wood during irradiation has an important role in radiation dose determination. Magaudda et al. (2001) stated that the dose of $10 \mathrm{kGy}$ is sufficient for practical disinfestations of Whatman paper-destroying insects. Freitag and Morrell (1998) reported on gamma radiation doses around $15 \mathrm{kGy}$ to be adequate to combat pests in wood (predominantly insects). They have also stated that the doses for extermination of Xylophagous microorganisms in wood are much higher than for sterilisation of other materials. Csupor et al. (2000) irradiated wood decayed by Xylophagous fungi in the range from 2 to $1400 \mathrm{kGy}$, and they concluded that $12 \mathrm{kGy}$ is sufficient for safe sterilisation of wood against fungi. The European Standard EN 113 (CEN, 1996) requires doses between 25 and $50 \mathrm{kGy}$ for wood sterilisation in lab testing procedures.

The treatment time depends on the power of the irradiation source, and there is no significant difference if the wood was irradiated with a weaker source for a longer time or with a stronger source for a shorter time (Unger et al., 2001; Hasan, 2006 mentioned Ražem, 2005). The important quantity is the absorbed dose (the amount of absorbed energy per mass unit) which irradiated substance receives (Fairand and Ražem, 2010). On the contrary Curling and Winandy (2008) reported that dose rate and total dose of gamma radiation differently affect both, bending strength and some chemical components in tested wood.

\section{Other applications of gamma radiation to wood}

One of the interesting areas of application of gamma rays and X-rays is in non-destructive analysis of density and water content and their distribution in solid wood, and the woodbased materials, i.e. wood panels (Davis et al. 1993, Lu and Lam, 1999). Karsulovič et al. (2002) used gamma irradiation in their studies for non-destructive detection of decay and other defects in logs. In this way, the quality of the timber can be to some extent predicted prior to mechanical processing. Because of extremely high energy of gamma radiation, it penetrates through the entire cross section of wood. Consequently, gamma rays can be used as a catalyst for polymerization of monomers in monomer-impregnated wood as well as for chemical modification of wood to create wood-plastic composites - WPC (Chawla, 1985; Sheikh and Afshar Taromi, 1993; Bakraji et al. 2001; Bakraji et al., 2002). Struszczyk et al. (2004) mentioned three possible uses of gamma radiation:

a. as pre-treatment in the chemical modification of cellulose;

b. as the initiator of the catalytic polymerization of monomers in the cellulose chain and

c. as pre-treatment for further chemical processing of cellulose in order to improve its solubility. 
Klimentov and Bysotskaia (1979); Chawla (1985) and Šimkovic et al. (1991) reported that gamma irradiation as a pre-treatment for the "softening" of wood prior to chemical processing, can significantly reduce the use of chemicals. Oldham et al. (1990) used gamma radiographic technique for analysing wood destruction by fire. They determined the efficiency of fire retardants by measuring the difference in absorbed gamma radiation energy in wood protected by these retardants before and after burning the wood. Bogner (1993) and Bogner et al. (1997) used different surface activators in order to achieve greater adhesion of adhesives to wood. Among other used activators, gamma radiation at different doses was also used. The results show that after treatment of wood by gamma radiation in doses range of 0 and $100 \mathrm{kGy}$, glue improves adhesion to wood and thus increases the strength of glued bonds. The first investigations of the influence of gamma radiation on lignocellulose materials, in terms of increasing the solubility of insoluble high-polymerized sugars such as cellulose, were performed by Klimentov and Bysotskaia (1979) and Klimentov et al. (1981).

\section{The influence of gamma radiation on wood}

Sterilisation by gamma radiation is very easy, fast and effective, but at doses higher than disinfestation doses it changes the molecular structures not only in wood decaying organisms but also in wood cell walls. Although Severiano et al. (2010) reported no influence of gamma radiation on some wood physical, thermal and mechanical properties in the radiation dose range between 25 and $100 \mathrm{kGy}$, the majority of other studies reported significant influence of gamma radiation on wood properties.

\subsection{Chemical properties of gamma irradiated wood}

The random break-up of cellulose chains in gamma irradiated wood is a typical reaction (Seaman et al., 1952; Kenaga and Cowling, 1959). Seifert (1964), Tabirih et al. (1977) and Cutter et al. (1980) found that the holocellulose portion of cell walls was degraded by gamma irradiation. After exposure of cypress wood (Pseudotsuga mensziessi) and tulipwood (Liriodendron tulipifera) to gamma rays, Lhoneaux et al. (1984) confirmed the occurrence of ultra structural changes in the cell walls of tested wood species. Following the above research results, Fengel and Wegener (1989) reported that gamma irradiation changes the anatomical and chemical structure of wood, but also the physical and mechanical properties. Seifert (1964) also found that small doses of gamma radiation lead to a destruction of hemicelluloses' pentose creating new compounds and new chemical bonds. Chawla (1985) reported that up to the dose of $500 \mathrm{kGy}$ the increase of wood solubility occurs primarily because of hemicelluloses depolymerisation and destruction. The influence of gamma radiation was also investigated on compounds of cellulose-acetate and cellulose nitrate (Fadel and Kasim, 1977; Zamani et al., 1981; Subrahmanyam et al., 1998). They came to the conclusion that also modified cellulose chains broke up. Seifert (1964) came to the conclusion that, an average increase of $25 \mathrm{kGy}$ of gamma radiation caused a loss of $1 \%$ cellulose in the dose range of $0-1 \mathrm{MGy}$. This proportional loss in cellulose crystallinity with increasing radiation dose was confirmed by Zamani et al. (1981) in a narrower interval of doses from 0 to $0.5 \mathrm{MGy}$. Fedel and Kasim (1977) successfully used cellulose-acetate as an indicator of the amount of absorbed energy of gamma irradiated objects, which reaffirms the proportionality between the reduction of cellulose crystallinity and gamma radiation dose. 
Summary of data collected from the literature on chemical changes of wood caused by gamma radiation are presented in Table 1 and in Figure 1.

\begin{tabular}{llll}
\hline $\begin{array}{l}\text { Characteristics } \\
\text { of compounds }\end{array}$ & Change & Dose & Reference \\
\hline $\begin{array}{l}\text { Degree of } \\
\text { crystallinity of } \\
\text { cellulose }\end{array}$ & $\begin{array}{l}50 \% \text { reduction } \\
\text { unchanged } \\
\text { rapid reduction }\end{array}$ & $\begin{array}{l}0,95 \times 10^{6} \mathrm{kGy} \\
\text { up to } 300 \mathrm{kGy} \\
\text { above } 1000 \mathrm{kGy} \\
100 \% \text { reduction }\end{array}$ & $\begin{array}{l}\text { Cutter \& McGinnes (1980) } \\
\text { Tsutomu et al. (1977) } \\
\text { Tsutomu et al. (1977) } \\
\text { Cutter \& McGinnes (1980) }\end{array}$ \\
\hline $\begin{array}{l}\text { Degree of } \\
\text { polymerisation of } \\
\text { cellulose }\end{array}$ & cellulose cross linking & up to $1 \times 10^{-3} \mathrm{kGy}$ & Seifert (1964) \\
\hline Cellulose & strong decrease of DP & above $10 \mathrm{kGy}$ & Fengel \& Wegener (1989) \\
& no change & up to 31,6 kGy & Seifert (1964) \\
& 6 to $12 \%$ degradation & $31,6 \mathrm{kGy}$ & Seifert (1964) \\
& $82 \%$ degradation & $1778,3 \mathrm{kGy}$ & Seifert (1964) \\
& complete degradation & $6,55 \times 10^{3} \mathrm{kGy}$ & Fengel \& Wegener (1989) \\
\hline Lignin & no change & up to 31,6 kGy & Seifert (1964) \\
& $10 \%$ degradation & $1778,3 \mathrm{kGy}$ & Seifert (1964) \\
& $15 \%$ degradation & $19 \times 10^{3} \mathrm{kGy}$ & Cutter \& McGinnes (1980) \\
& & & Tabirih et al. (1977) \\
\hline
\end{tabular}

Table 1. Summary of data on the influence of various doses of gamma radiation onto main wood compounds.

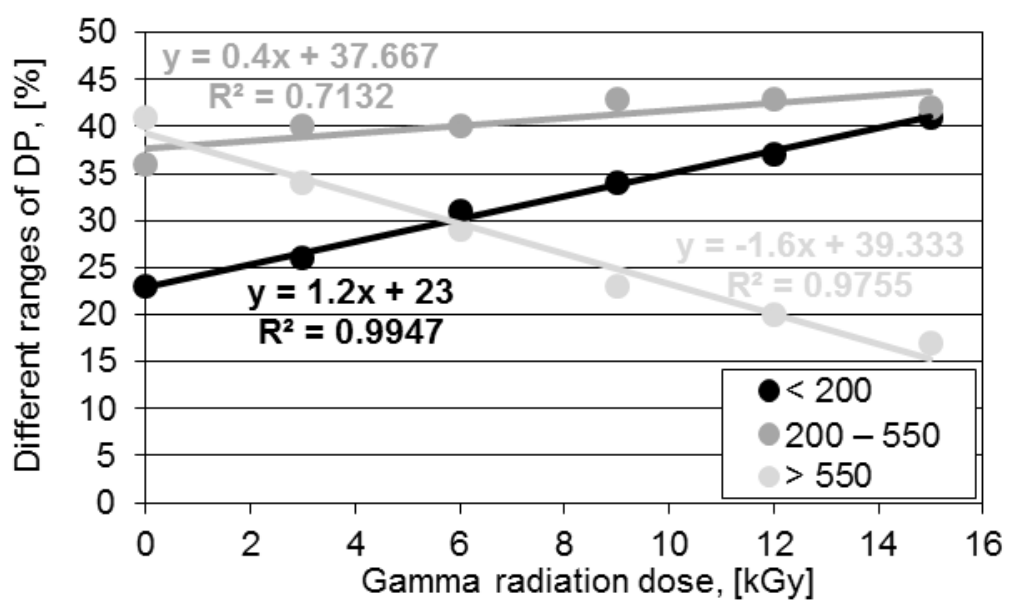

Fig. 1. Different ranges of polymerisation degree (DP) of cellulose depending on gamma radiation dose (according to Struszczyk et al. (2004)).

Seifert (1964) found an increasing amount of free radicals in wood after gamma radiation, which could be effective after irradiation for wood modification in terms of their repolymerisation. Fengel and Wegener (1989) and Tišler and Medved (1997) discussed that the cellulose chains continue breaking down during 100 days after finishing the gamma 
treatment. Curling and Winandy (2008) gamma irradiated southern pine sapwood specimens (Pinus spp.) at a range of nine total irradiation doses (from a ${ }^{60} \mathrm{Co}$ source) applied at two different dose rates: $8.5 \mathrm{kGy} / \mathrm{h}$ (total doses of 15.0, 25.0, and $50.0 \mathrm{kGy}$ ) and 16.9 $\mathrm{kGy} / \mathrm{h}$ (total doses of 15.0, 20.0, 25.0, 37.5, 50.0 and 75.0 kGy). Gamma radiation at higher $(16.9 \mathrm{kGy} / \mathrm{h})$ dose rate clearly had more negative effect on Mason lignin levels than did either the steam sterilization or gamma radiation at lower $(8.5 \mathrm{kGy} / \mathrm{h})$ dose rate. Gamma radiation at the $16.9 \mathrm{kGy} / \mathrm{h}$ dose rate reduced Klason lignin content from $29.5 \%$ to 28.1 and to $27.5 \%$, but seemed to have little on-going effect related to dose accumulation. They also found that galactans, which are side-chain constituents of the hemicelluloses, are affected sooner and to a greater extent than xylans or mannans that represent the primary backbone of the hemicellulose polymers. Furthermore arabinan was probably unaffected by various radiation regimes. The authors suspected that the $\beta-(1 \rightarrow 3)$ linkage of the arabinan-xylan bond was less affected by radiation than the $\beta-(1 \rightarrow 6)$ linkage of the galactan-mannan bond.

\subsubsection{Total amount of water-soluble carbohydrates, (TSC)}

Hasan (2006) and Despot et al. (2007; 2008) measured the total amount of water-soluble carbohydrates (TSC) according to Rapp et al. (2003). They used the following procedure: Five oven-dried specimens of each group were milled together for $60 \mathrm{~s}$ in a heavy vibratory disc mill (Herzog Maschinenfabrik, Osnabrück, Germany). $400 \mathrm{mg}$ of wood powder were mixed up with one drop of detergent and $20 \mathrm{ml}$ distilled water in $50 \mathrm{ml}$ flasks. Afterwards, the flasks were shaken at $20^{\circ} \mathrm{C}$ for $60 \mathrm{~min}$ with a vibration of $120 \mathrm{~min}^{-1}$ and filtered through glass filter paper. The filtrates were diluted with distilled water in proportion 1:5.

The reagent for optical spectrophotometry was prepared by dissolving $2 \mathrm{~g}$ of dihydroxytoluol (Orcin) in 11 of $97 \%$ sulphuric acid. For analysing the carbohydrate content $1 \mathrm{ml}$ of dilution was mixed with $2 \mathrm{ml}$ reagent in a test-tube and heated for $15 \mathrm{~min}$ at $100{ }^{\circ} \mathrm{C}$ in a Thermo-block (Merck TR205). After cooling to room temperature, the dilution was analysed at $540 \mathrm{~nm}$ with a Merck SQ 115 filter-photometer. The TSC was calculated after calibration with a glucose standard between 20 and 200 ppm leading to extinction between 0.12 and 1.32 .

Hasan $(2006)$ and Despot et al. $(2007 ; 2008)$ found a strong influence of gamma irradiation on TSC. As gamma radiation causes destruction of cellulose chains and the resulting smaller cellulose fragments are easily soluble, increasing of TSC with increasing radiation dose was expected. They found no significant influence of time after gamma treatment on TSC (Figures 2 and 3).

The sensitiveness of the TSC content to reveal changes in the carbohydrate structure of wooden materials was shown in earlier studies with thermally modified timber (TMT) where TSC was significantly reduced with ascending heat treatment temperature and increasing heat-induced loss of mass (Welzbacher et al., 2004; 2009). Thus, the extraction of soluble carbohydrates appeared to be a sensitive method to display degradation of carbohydrates (Hasan, 2006; Despot et al., 2007; 2008) and is therefore also considered as a suitable tool to characterize the treatment intensity of gamma radiation.

According to Fengel and Wegener (1989) and Tišler and Medved (1997), the highest TSC should be observed 150 days after gamma radiation. In contrast to mass loss by leaching, TSC did not decrease over time. Accordingly, the radical recombination is probably limited to higher mol mass fragments but not to lower fragments, which appear as TSC. 


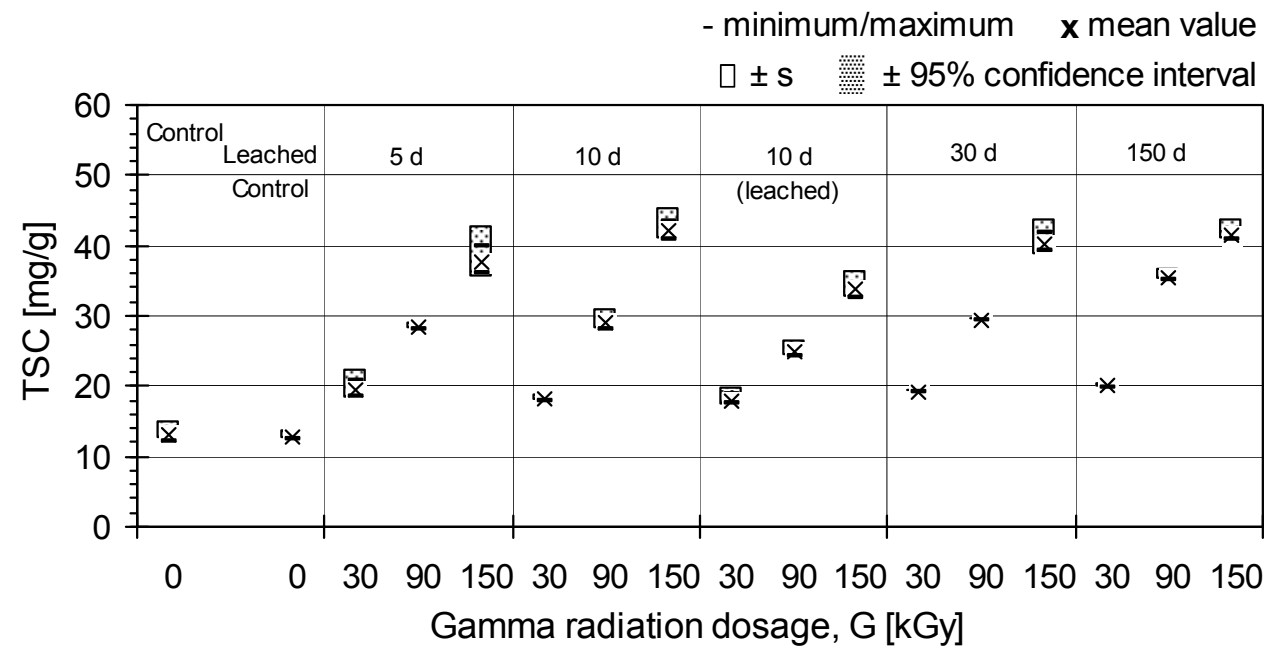

Fig. 2. Total amount of water-soluble carbohydrates (TSC) of leached and non-leached specimens irradiated with different gamma doses for different time intervals after gamma irradiation; $\mathrm{n}=3$ (Despot et al., 2007).

After leaching, irradiated specimens still had significantly greater TSC than non-irradiated and non-leached controls. The TSC relative to the controls $\left(\mathrm{TSC}_{\mathrm{r}}\right)$ was calculated for each radiation dose as a ratio of mean TSC of gamma irradiated specimens and the mean TSC of non-irradiated and non-leached controls. $\mathrm{TSC}_{\mathrm{r}}$ of non-leached and leached specimens showed linear correlation with the radiation dose (Figure 3).

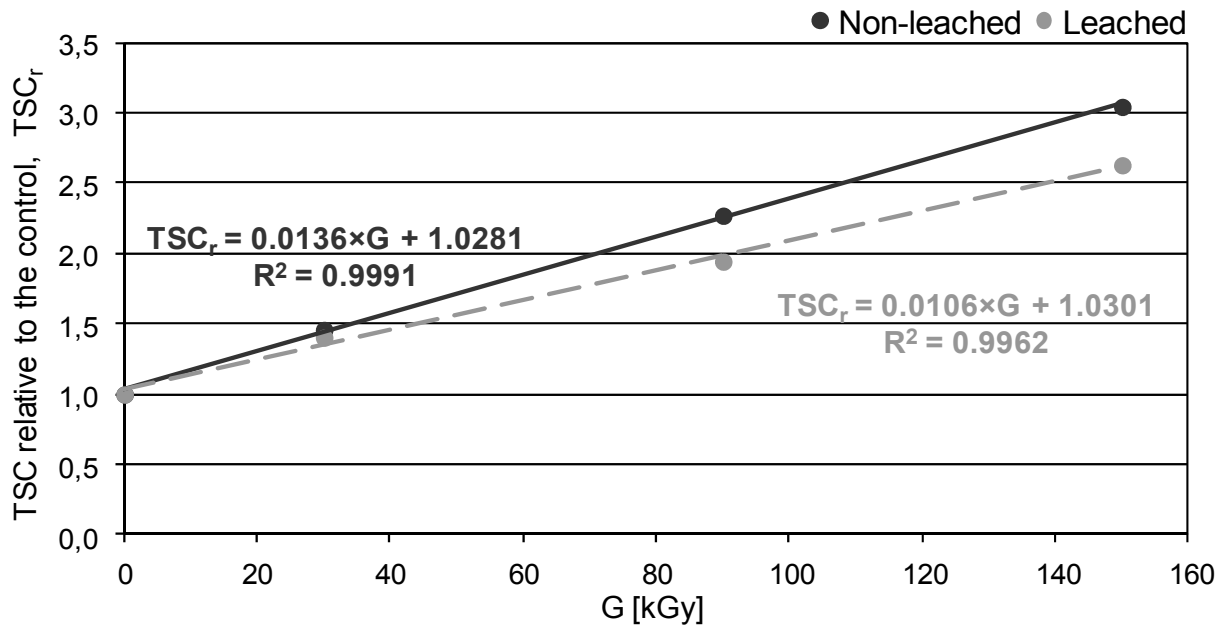

Fig. 3. Correlation between total amount of water-soluble carbohydrates relative to controls $\left(\mathrm{TSC}_{\mathrm{r}}\right.$ ) and gamma radiation dose $(\mathrm{G})$ for non-leached and leached specimens

(Despot et al., 2007). 
All these studies lead to the conclusion that due to breaking the chains of cellulose in wood cell wall, there must be some changes in physical and mechanical properties of gammairradiated wood. These changes should mostly influence the hygroscopicity (Fengel and Wegener, 1989) and tension strength of gamma-irradiated wood, because it becomes more brittle (Divos and Bejo, 2005). Furthermore, gamma irradiated wood is more susceptible to chemical and enzymatic degradation (Seifert, 1964; Klimentov and Bysotskaia, 1979; Klimentov et al., 1981; Ardica et al., 1984; Šimkovic et al., 1991; Magaudda et al., 2001; Struszczyk et al., 2004; Despot et al., 2006; Hasan, 2006 and Hasan et al., 2006a; 2008).

\subsection{Physical properties of gamma irradiated wood}

Gamma radiation lead to significant colour changes of wood. With increasing radiation dose the darkening of the specimens increased as can be seen from Figure 4.

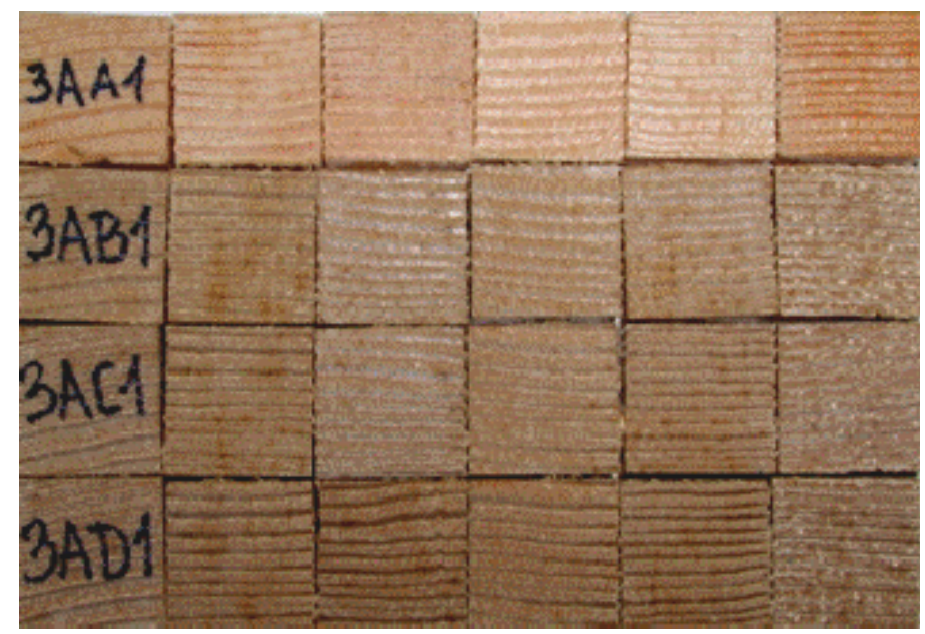

Fig. 4. Colour change of specimens used for mass loss determination, 3AA - control group, $\mathbf{3 A B}$ - group irradiated with $30 \mathrm{kGy}, 3 \mathrm{AC}$ - group irradiated with $90 \mathrm{kGy}$ and $3 \mathrm{AD}$ - group of specimens irradiated with $150 \mathrm{kGy}$.

\subsubsection{Decrease in mass caused by gamma irradiation}

On the question whether there is any loss of mass or density of the wood due to gamma radiation, Loos (1962) in his studies noted no significant changes in the density of wood. Seifert (1964) stated the possibility of negligible loss of $\mathrm{CO}_{2}$ from wood due to radiation induced chemical reactions. However, wood irradiated in the presence of air might absorb atmospheric nitrogen in small quantities (Seifert, 1964). Tsutomu et al. (1977) reported on a very small effect of gamma radiation on specific gravity of wood and cellulose. Curling and Winandy (2008) reported that density of southern pine sapwood stayed unchanged by any tested level of irradiation dose or dose rate of gamma radiation. Hasan (2006) and Despot et al. (2007) measured oven dry mass of Scots pine (Pinus sylvestris) specimens. They determined no statistically significant changes in mass before and after irradiation at a confidence interval of $95 \%$ although specimens were gamma irradiated in plastic bags with the presence of air (Figure 5). 


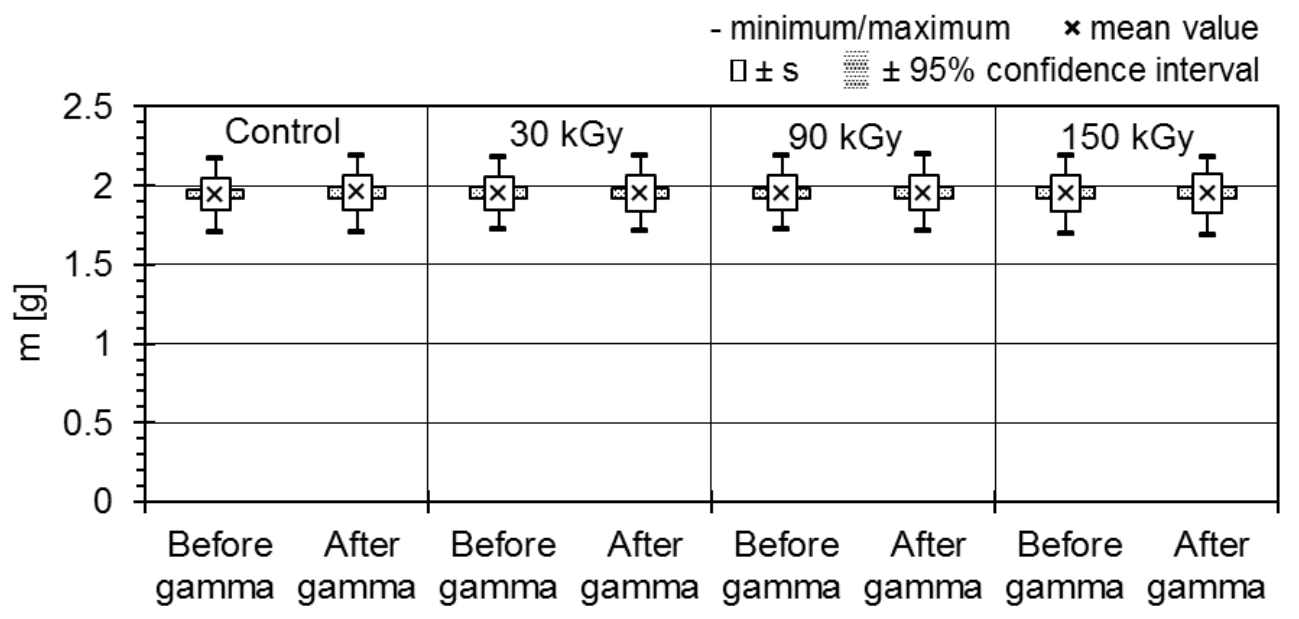

Fig. 5. Comparison of dry mass of specimens before and after gamma radiation.

\subsubsection{Decrease in mass by leaching, $(\mathrm{dm})$}

Leaching in water of Scots pine sapwood specimens caused a significant decrease in mass $(\mathrm{dm})$. A strong linear correlation was found between gamma radiation doses $(\mathrm{G})$ and $\mathrm{dm}$ (Despot et al., 2007; Figure 6). This might be explained by random break up of cellulose

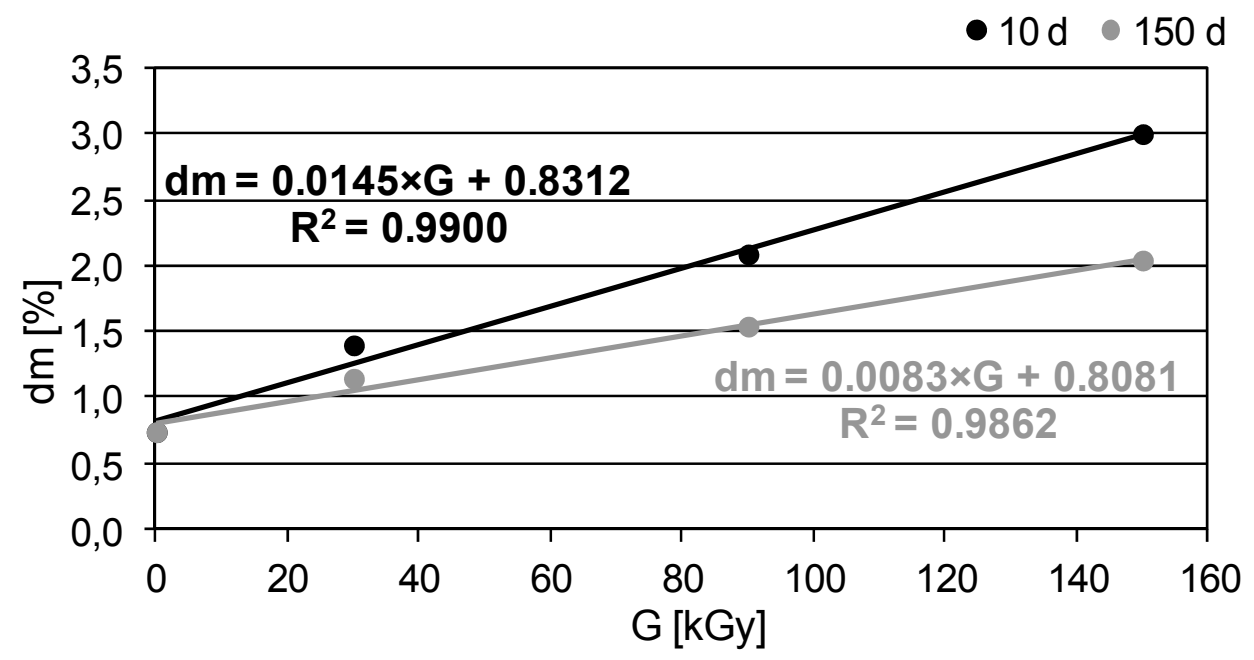

Fig. 6. Correlation between decrease in mass $(\mathrm{dm})$ by leaching and gamma radiation dose (G) for 10 and 150 days after gamma treatment. 
chains and the solubility of smaller cellulose fragments in water (Seifert, 1964; Tabirih et al., 1977; Šimkovic et al., 1991). Despot et al. (2007) reported that for 10 days after gamma treatment dm was significantly higher than after 150 days for each applied dose (Table 2). This finding is in contrast to the results of Fengel and Wegener (1989) and Tišler and Medved (1997), but it can easily be explained by repolymerisation reactions between the free radicals caused by irradiation (Seifert, 1964; Bogner et al., 1997).

\begin{tabular}{ccccccc}
\hline Time after gamma treatment & \multicolumn{3}{c}{10} \\
$\begin{array}{c}\text { [days] } \\
\text { Gamma radiation dose, }\end{array}$ & 30 & 90 & 150 & 30 & 90 & 150 \\
\cline { 2 - 7 } G [kGy] & 1.1773 & 1.6206 & 2.2598 & 0.9146 & 1.2781 & 1.8308 \\
Minimum dm [\%] & 1.3999 & 2.0900 & 3.0026 & 1.1471 & 1.5423 & 2.0438 \\
Mean dm [\%] & 1.9200 & 3.0700 & 4.4500 & 1.2916 & 1.8732 & 2.3433 \\
Maximum dm [\%] & 0.2675 & 0.5449 & 0.9213 & 0.1126 & 0.1741 & 0.1805 \\
Standard deviation [\%] & 19.11 & 26.07 & 30.68 & 9.82 & 11.29 & 8.83 \\
Coefficient of variation [\%] & 6.2780 & 8.3589 & 9.0220 & 4.8216 & 8.8164 & 14.2067 \\
T - value & 0.0020 & 0.0001 & 0.00 & 0.0271 & 0.00 & 0.00 \\
Probability of mistake [\%] & +++++ & +++ & +++ & +++ & +++ \\
Signification degree & +++ & +++ & ++
\end{tabular}

Table 2. Results of statistical analysis on differences of decrease in mass ( $\mathrm{dm}$ ) by leaching between non-irradiated controls and with different doses irradiated specimens 10 and 150 days after the gamma treatment for $95 \%$ confidence interval; $\mathrm{n}=15 ;$ (+ significant, ++ high significant, +++ highest significant).

\subsubsection{Maximum swelling, $\left(\alpha_{\mathrm{MAX}}\right)$}

Panshin and de Zeeuw (1980) stated that the arrangement of the cellulose crystals in microfibrils can be observed by the existence of amorphous zones along the microfibril length, in which the crystallinity is interrupted. These zones allow the penetration of chemicals into the microfibrils. Furthermore, the gamma radiation caused break-up of cellulose to shorter chains, which are water-soluble, and it most likely leads to an "opening of additional microcracks", in which water molecules can easily penetrate. Consequently it is to expect that gamma irradiated wood swells faster but also more than non-irradiated wood. Results by Hasan (2006), Hasan et al. (2006b) and by Despot et al. (2007; 2008) showed no significant influence of radiation dose on maximum swelling, neither in radial ( $\left.\alpha_{R} \operatorname{MAx}\right)$ nor in tangential ( $\alpha_{T}$ MAX) direction (Figure 7$)$. Leached irradiated wood showed significantly higher $\alpha_{R}$ MAX compared to non-leached wood. With increasing radiation dose the difference in $\alpha_{\mathrm{R} \text { MAX }}$ between leached and non-leached specimens became more significant (Despot et al., 2007). Obviously, cellulose chains and lignin (Curling and Winandy, 2008) were affected by gamma radiation and the "plywood effect" of the wood rays has been reduced and $a_{R}$ MAX increased. In contrast, $\boldsymbol{a}_{\mathrm{T}}$ MAX of leached irradiated wood significantly decreased. It can be explained by the decreasing of tangential vessel wall thickness, ray cell double-wall thickness and latewood fibre double-wall thickness, as described by Tabirih et al. (1977) and Cutter et al. (1980). Despot et al. $(2007 ; 2008)$ found no significant influence of time after gamma radiation on $\mathrm{a}_{\mathrm{MAX}}$. 


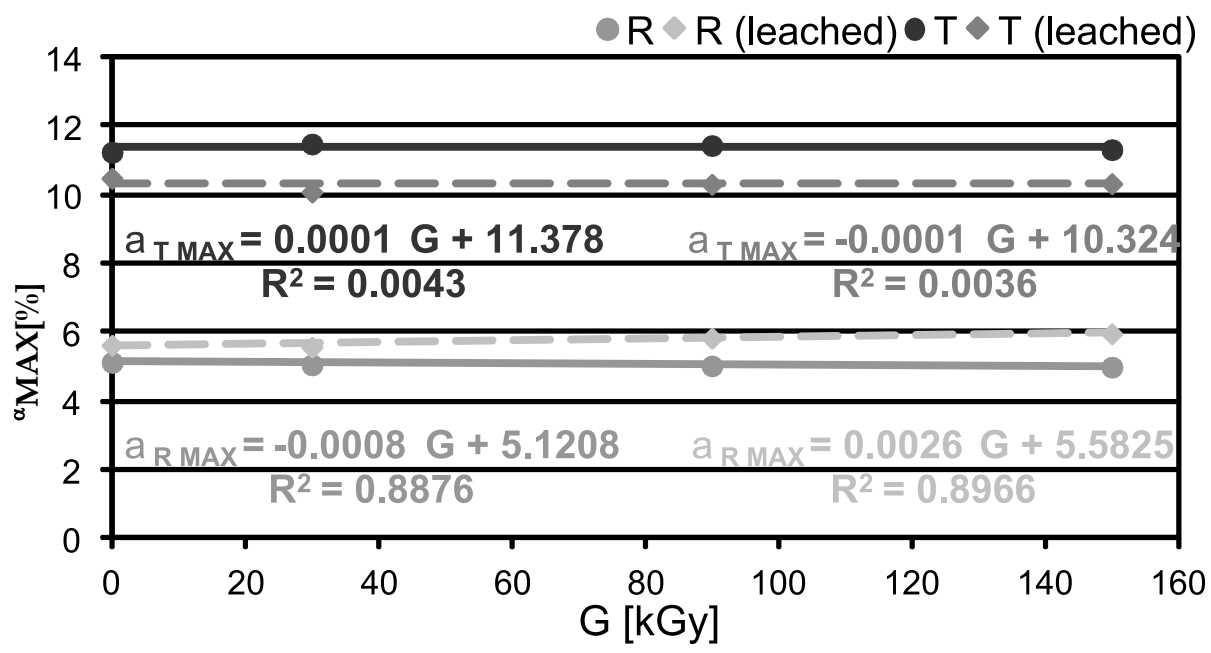

Fig. 7. Correlation between maximum swelling $\left(\mathrm{a}_{\mathrm{MAx}}\right)$ in radial $(\mathrm{R})$ and tangential $(\mathrm{T})$ direction of non-leached and leached specimens and gamma radiation dose $(\mathrm{G})$.

\subsubsection{Maximum moisture content ( $M \mathrm{C}_{\mathrm{MAX}}$ )}

Maximum moisture content, $\left(\mathrm{MC}_{\mathrm{MAX}}\right)$ of each irradiated group of specimens was equal or higher than the MC of controls (Hasan, 2006; Hasan et al., 2008). It is well known, that glucose and other simple sugars make wood considerably more hygroscopic (Fengel and Wegener, 1989). No significant influence of gamma radiation dose on $\mathrm{MC}_{\mathrm{MAX}}$ was found (Figure 8). Radiation dose did not have significant influence on maximum $\mathrm{MC}$, the same as

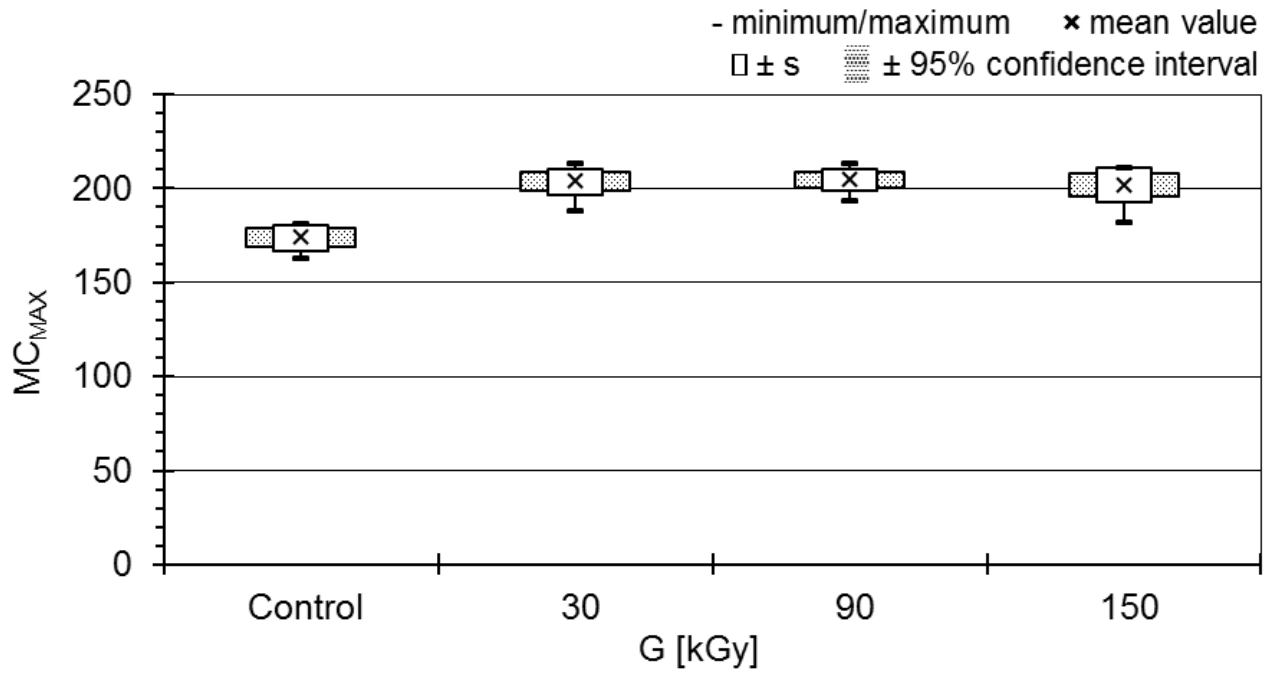

Fig. 8. Correlation between maximal moisture content $\left(\mathrm{MC}_{\mathrm{MAX}}\right)$ and gamma radiation dose $(\mathrm{G})$. 
on maximum swelling (Despot et al., 2007). It is probable that specimens irradiated with higher radiation dose reaches faster the $\mathrm{MC}_{\mathrm{MAX}}$.

\subsection{Mechanical properties of gamma irradiated wood}

Loos (1962), Ifju (1964), Shuler et al. (1975), El-Osta et al. (1985), Hasan (2006), Hasan et al. (2006b) and Despot et al. $(2007 ; 2008)$ verified that gamma-radiation-induced depolymerisation causes a significant decrease in wood strength. Curling and Winandy (2008) reported that dose rate and total dose of gamma radiation differently affected bending strength of pine wood (Pinus sp.). They found that cumulative duration of radiation exposure period appeared to be more critical than total dose in determining overall strength loss. When total gamma radiation dose was directly compared at or near the critical doses required to achieve sterilization, shorter exposures using higher dose rates affected strength less than longer exposures using lower dose rates (Curling and Winandy, 2008). Loos (1962) comes to $1 \mathrm{kGy}$ as a threshold - wood toughness had a tendency of linear increase, followed by a progressive decrease. Gamma radiation depolymerised wood had significantly reduced tensile strength, although early wood showed an initial increase in tensile strength (Ifju, 1964). Tsutomu et al. (1977) reported on considerable decrease in strength of wood with increasing irradiation dosage, depending remarkably on loading modes. Testing the tensile and compression strengths parallel to the grain of gamma-irradiated wood, El-Osta et al. (1985) have found a slight increase in tensile and compression strength till the dose of 1.4 kGy. Increasing the gamma radiation dose, tensile and compression strengths constantly decreased. Decrease in tensile strength was more pronounced than that in compression strength. Researching dynamic modulus of elasticity of spruce wood (Picea sp.) Shuler (1971) noted the increase of the modulus in the range of radiation doses from 0 to $1 \mathrm{kGy}$ while further increase of radiation dose decreased dynamic modulus of elasticity.

Shuler et al. (1975) measured bending strength of American elm (Ulmus americana), which was exposed to gamma radiation during growth. The results showed that small doses of radiation up to $0.22 \mathrm{kGy}$ increased bending strength on average by $30 \%$, and further increase in dose lead to a continuous and significant decrease of bending strength. Measuring the bending strength, Shuler et al. (1975) noted the increase of the modulus of elasticity in the range of radiation doses from 0 to $0.22 \mathrm{kGy}$ while further increase of radiation dose lead to the decrease of the modulus of elasticity and decrease of the proportionality limit.

Csupor et al. (2000) irradiated wood in the range of 2 - $1400 \mathrm{kGy}$ and concluded that a dose of $12 \mathrm{kGy}$ was sufficient for wood sterilization while modulus of elasticity at this dose was not significantly reduced $(0.2 \%)$. Tests have also shown that an initially higher modulus of elasticity decreased more rapidly with increasing radiation dose. Divos and Bejo (2005) reported on a steady and a continuous decrease of modulus of elasticity (MOE) for all tested wood species in the range of gamma radiation dose from 130 to $770 \mathrm{kGy}$. Results also showed a difference in the intensity decrease of MOE between the wood species, and wood density had significant influence on decrease intensity of the MOE. Lower densities resulted in faster decrease in MOE. Interpolating the obtained data Divos and Bejo (2005) concluded that the dose sufficient for wood sterilization not significantly decreased MOE. In the graphs (Figure 9) an inversely proportional correlation between the gamma radiation dose and dynamic MOE was visible with high degrees of determination. 

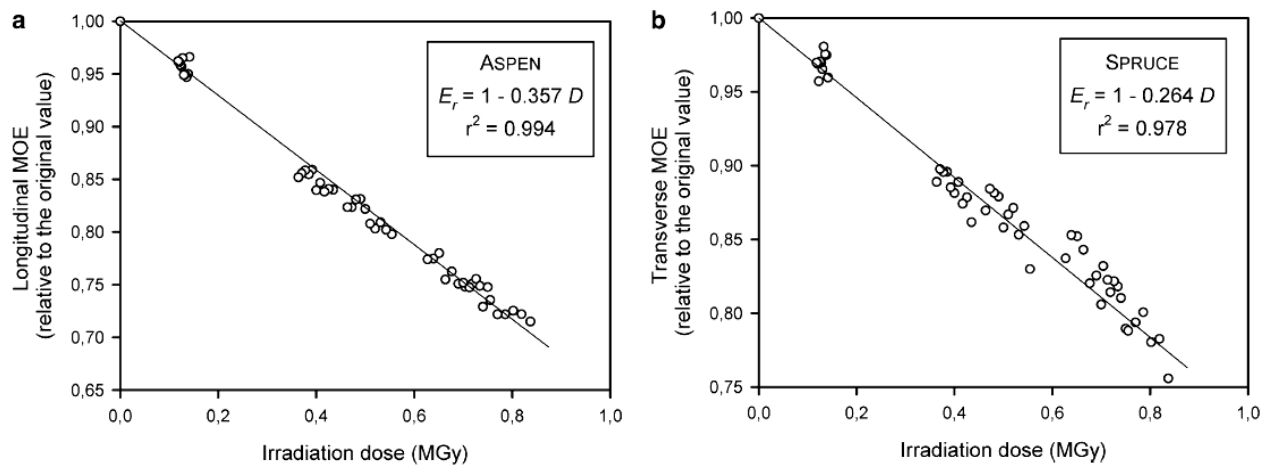

Fig. 9. Correlation between dynamic MOE and gamma radiation dose: a) longitudinal MOE of aspen; b) transverse MOE of spruce (taken from: Divos and Bejo, 2005).

\subsubsection{Structural integrity of gamma irradiated wood}

The High-energy multiple impact (HEMI) test has been developed to characterise the effect of thermal and chemical modification procedures as well as fungal and bacterial decay on the structural integrity of wood. The development and optimization of the HEMI-test have been described by Brischke et al. (2006a). In studies on the effect of gamma radiation onto structural integrity of gamma irradiated wood (Hasan, 2006; Hasan et al., 2006b; Despot et al., 2007; 2008) the following procedure was applied:

Five of ten specimens were placed in the bowl (140 mm inner diameter) of a heavy vibratory impact ball mill, together with one steel ball of $35 \mathrm{~mm} \varnothing, 3$ of $12 \mathrm{~mm} \varnothing$, and 3 of $6 \mathrm{~mm} \varnothing$. The bowl was shaken for $60 \mathrm{~s}$ at a rotary frequency of $23.3 \mathrm{~s}^{-1}$ and a stroke of $12 \mathrm{~mm}$. This crushing procedure was repeated on another five specimens (Figure 10). The fragments of the ten specimens were fractionated with slit screens on an orbital movement shaker (amplitude: $25 \mathrm{~mm}$, rotary frequency: $250 \mathrm{~min}^{-1}$, duration: $10 \mathrm{~min}$ ).
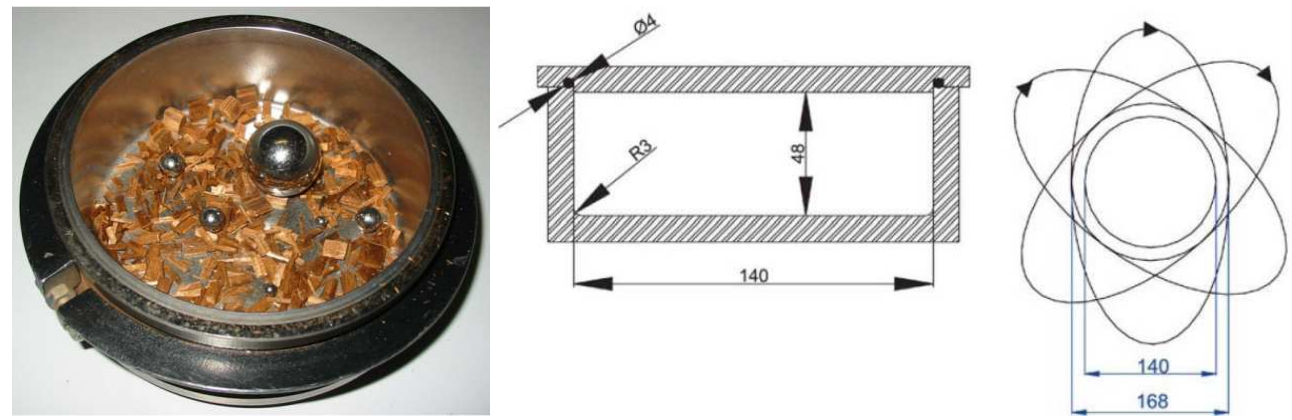

Fig. 10. Experimental set up of the High-energy multiple impact (HEMI) test. Left: Bowl with steel balls of different sizes and wood fragments. Right: Cutting scheme of the steel bowl and movement schedule. 
The following five fractions were separated and weighed: Fraction 1 (F1, $>5 \mathrm{~mm})$, Fraction 2 (F2, 3-5 mm), Fraction 3 (F3, 2-3 mm), Fraction 4 (F4, 1-2 mm) and Fraction 5 (F5, <1 mm). The following values were calculated:

The degree of integrity $I$, which is the ratio of the mass of the 10 biggest fragments to the mass of all fractions $m_{\text {all }}$ after crushing:

$$
I=\frac{m_{10} \text { biggest fragments }}{m_{\text {all }}} \times 100[\%]
$$

The fine fraction F5 is the ratio of the mass of fraction $5(<1 \mathrm{~mm})$ to the mass of all fractions $m_{\text {all }}$ multiplied by 100 . Finally, the resistance to impact milling (RIM) was calculated from $I$ and F5 as follows:

$$
R I M=\frac{I-(3 * F 5)+300}{4}[\%] .
$$

\subsubsection{Resistance to impact milling (RIM)}

The resistance to impact milling (RIM) decreased significantly with increasing radiation dose. Time after gamma treatment had no significant influence on RIM neither of nonleached nor of leached specimens (Despot et al. 2007; Figure 11).

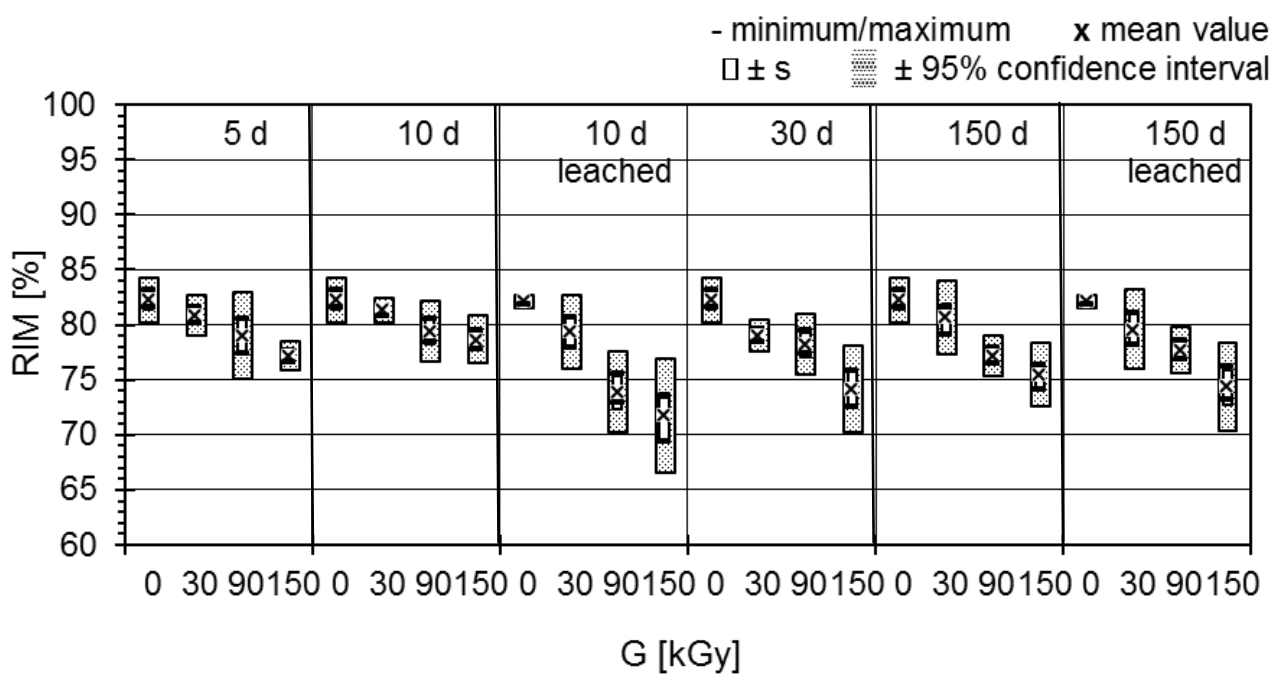

Fig. 11. Resistance to impact milling (RIM) of leached and non-leached specimens for different gamma doses $(G)$ and different periods after gamma treatment $(n=3 \times 10$ specimens).

Despot et al. (2007) and Hasan et al. (2006b) found linear dependence between RIM and G for both, non-leached and leached specimens. The elapsed time after gamma radiation did not influence the linear correlation between RIM and G (Table 3). 


\begin{tabular}{cccc}
\hline $\begin{array}{c}\text { Leaching } \\
\text { procedure }\end{array}$ & $\begin{array}{c}\text { Time after gamma } \\
\text { treatment [days] }\end{array}$ & Fitting curve equation & $\begin{array}{c}\text { Regression } \\
\text { coefficient, } \mathbf{R}^{2}\end{array}$ \\
\hline \multirow{2}{*}{ non- } & 5 & $\mathrm{RIM}=-0.0332 \times \mathrm{G}+81.989$ & 0.9933 \\
leached & 10 & $\mathrm{RIM}=-0.0246 \times \mathrm{G}+82.006$ & 0.9626 \\
& 30 & $\mathrm{RIM}=-0.048 \times \mathrm{G}+81.597$ & 0.9206 \\
\hline \multirow{2}{*}{ leached } & 150 & $\mathrm{RIM}=-0.0462 \times \mathrm{G}+81.951$ & 0.9769 \\
\hline
\end{tabular}

Table 3. Fitting curve equations for the relationship between RIM and G for non-leached and leached specimens at different periods after gamma treatment.

Despot et al. (2007) and Hasan et al. (2006b) calculated RIM relative to the controls $\left(\mathrm{RIM}_{\mathrm{r}}\right)$ for non-leached and leached specimens as the ratio between mean RIM of gamma treated specimens and mean RIM of non-leached controls. RIM $_{r}$ linearly depends on the radiation dose and decreases stronger for leached wood than for non-leached wood. Maximum reduction in RIM was $12 \%$ at the highest gamma dose (Figure 12).

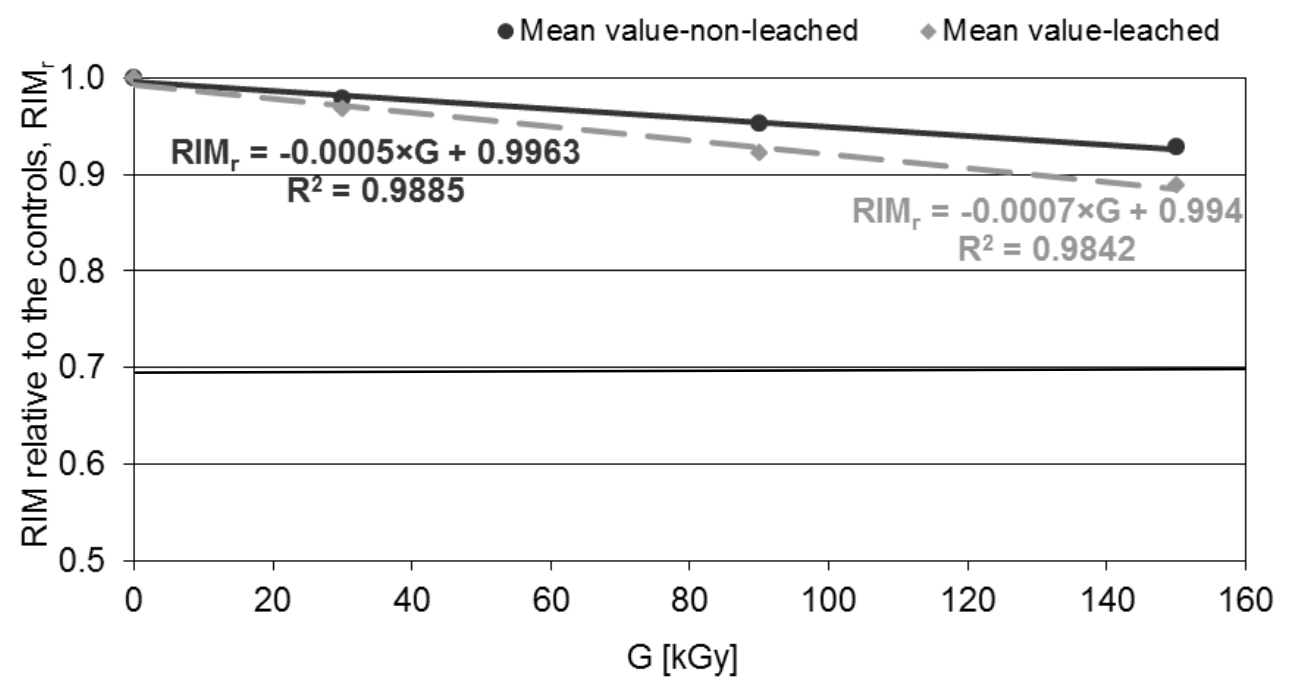

Fig. 12. Correlation between RIM relative to the controls $\left(\mathrm{RIM}_{\mathrm{r}}\right)$ of non-leached and leached specimens and gamma radiation dose (Despot et al. 2007).

Brischke et al. (2006a), Rapp et al. (2006), and Welzbacher et al. (2006) described the sensitive HEMI test, which is able to reveal fine changes in "dynamic strength properties" (increased brittleness). This has been confirmed for thermally and chemically modified timber (Welzbacher et al. 2007, 2011; Brischke et al. 2012) as well as for differently degraded timber, e.g. by different basidiomycetes, soft rot fungi and bacteria (Rapp et al., 2008; Brischke et al., 2009; Huckfeldt et al., 2010). Also the findings in this research confirmed the suitability of the HEMI test for detecting subtle differences in the mechanical properties of wood. In particular, it is the structural integrity, which affects the Resistance to impact milling RIM, wherefore the results of the HEMI test characterise structural changes on a cellular micro 
level. In contrast, macroscopic defects, such as cracks and splitting, will not affect the results, because they will be masked through finer fragmentation of the wood samples (Welzbacher et al., 2011). As a result of various different dynamic loads (impact bending, end grain bending, compression, cleaving, shearing, and buckling) the reduced structural integrity of the wood is reflected by the HEMI test (Welzbacher et al., 2011). The significant decrease in RIM through gamma radiation is therefore considered to be also attributed to the break-up of cellulose chains (Hasan et al., 2006b; Despot et al., 2007; 2008). This again coincides with the higher sensitivity of the HEMI-test to cellulose break down by brown rot fungi compared to white rot decay (Brischke et al., 2006b; 2008).

\subsection{Biological durability of gamma irradiated wood}

Despot et al. (2006) and Hasan et al. (2006a, 2008) used pine sapwood specimens, one group steam sterilised (at $123{ }^{\circ} \mathrm{C}$ for $30 \mathrm{~min}$ ) and second group of specimens gamma-irradiated in the range of doses of 30, 90 and $150 \mathrm{kGy}$. Specimens were subject to laboratory decay resistance tests. According to EN 113 (1996) the specimens were incubated in testing flasks with pure cultures of test fungi. They used brown- and white-rot fungi for the study. Mass loss by fungal decay (ML) was determined by weighing the oven-dry specimens before $\left(\mathrm{m}_{1}\right)$ and after $\left(\mathrm{m}_{3}\right)$ incubation to the nearest $1 \mathrm{mg}$ and according to equation (3):

$$
M L=\frac{m_{1}-m_{3}}{m_{1}} \times 100[\%]
$$

\subsubsection{Resistance against decay fungi}

As gamma radiation causes break-up of cellulose to shorter chains, which are water-soluble, and that leads to an "opening of additional microcracks", in which water molecules can easily penetrate. Consequently, gamma irradiated wood is also more accessible to enzymes of wood decaying fungi.

Only ten days after incubation, it was clearly visible, that irradiated specimens were more overgrown, than control steam sterilised controls, which indicates a higher susceptibility to biodegradation of gamma irradiated wood compared to non-irradiated wood (Hasan, 2006a; Hasan et al., 2008; Figure 13).
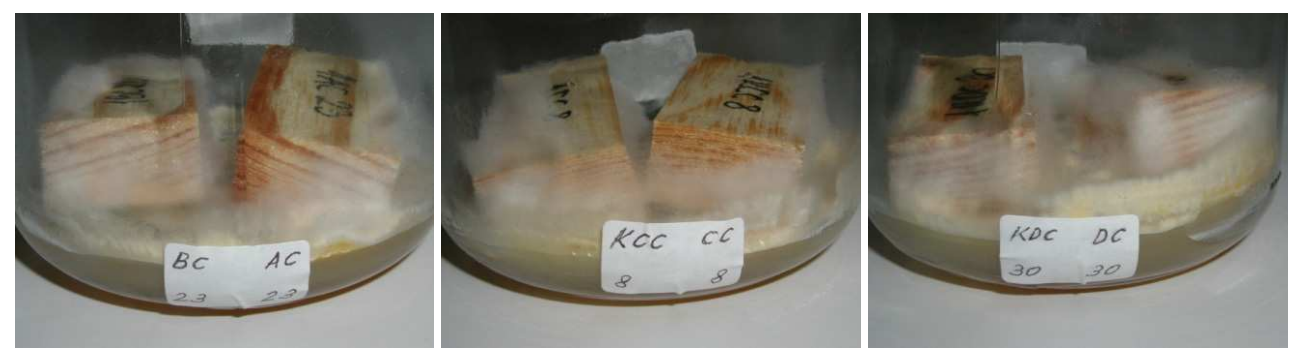

Fig. 13. Specimen pairs in testing flasks 10 days after exposure to brown-rot fungus Gloeophyllum trabeum (AC, KCC, KDC - non-irradiated controls, BC - specimen irradiated with $30 \mathrm{kGy}, \mathrm{CC}-90 \mathrm{kGy}$, DC - specimen irradiated with dose of $150 \mathrm{kGy}$ ). 


\section{Resistance against brown-rot fungi}

Visible difference in appearance (irregular shape and darker colour) between irradiated and autoclaved specimen after 16 weeks of exposure to the fungus G. trabeum indicated a significantly higher decay of the irradiated specimens (Hasan, 2006; Hasan et al., 2008). After 12 and 16 weeks of exposure to the fungus G. trabeum, average ML of irradiated and control specimens was more than $25 \%$, which proved that the fungus was virulent (EN 113: 1996). The difference in ML between irradiated and autoclaved specimens was slight and not significant after 4 weeks of incubation, except specimens irradiated with $150 \mathrm{kGy}$, whose ML was greatest. The difference in ML between controls and specimens irradiated with 30 kGy reached maximum after 8 weeks of incubation, while other two irradiated groups had no significant difference in ML comparing to control. During further incubation time the differences in ML between irradiated and control specimens decreased and after 16 weeks became insignificant (Figure 14).
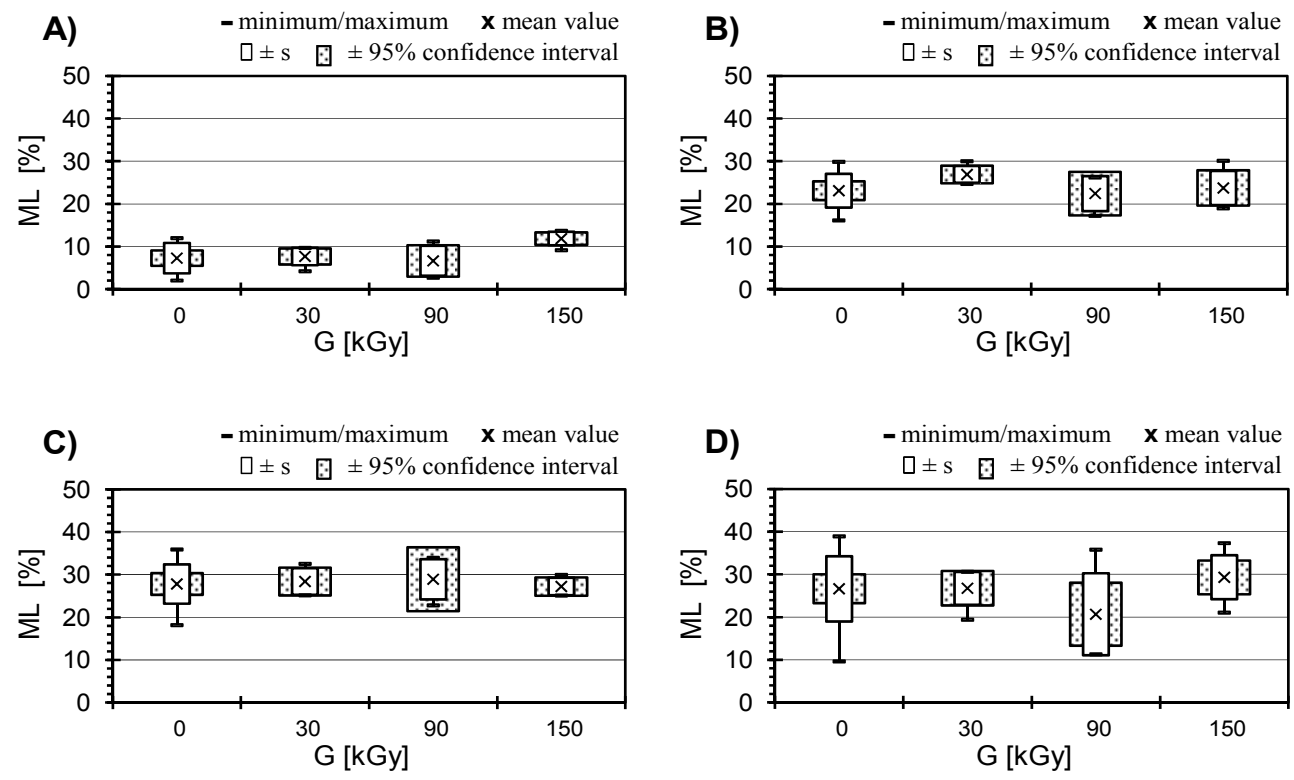

Fig. 14. Mass loss (ML) of autoclaved and irradiated specimens during exposure to fungus Gloeophyllum trabeum: A) 4 weeks incubation; B) 8 weeks incubation; C) 12 weeks incubation; D) 16 weeks incubation; (irradiated specimens n=7; G=0 kGy - autoclaved controls n=21).

Fungus $P$. placenta causes brown rot with broad and deep cracks. Clearly visible difference in appearance (cracks and irregular shape) between irradiated and autoclaved specimens after 16 weeks of incubation has been shown in Figure 15. 


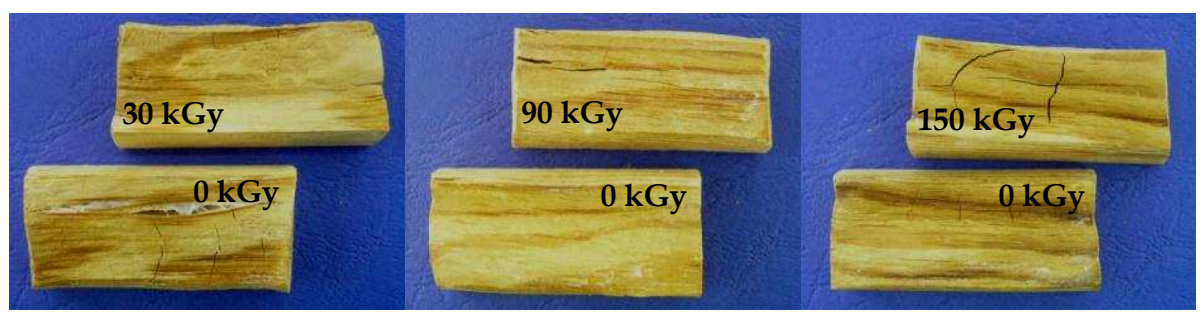

Fig. 15. Appearance of irradiated and autoclaved specimens after 16 weeks of exposure to fungus Poria placenta.

The difference in ML between specimens irradiated with 30 and $90 \mathrm{kGy}$ and autoclaved ones is slight and not significant after 4 weeks of incubation, while specimens irradiated with 150 kGy had significantly greater ML. During further incubation differences in ML between autoclaved and irradiated specimens increased but also between irradiated groups. During the all incubation period ML increased with radiation dose. Since P. placenta was more virulent and more aggressive fungus compared to G. trabeum, the obtained results are logical (Figure 16).
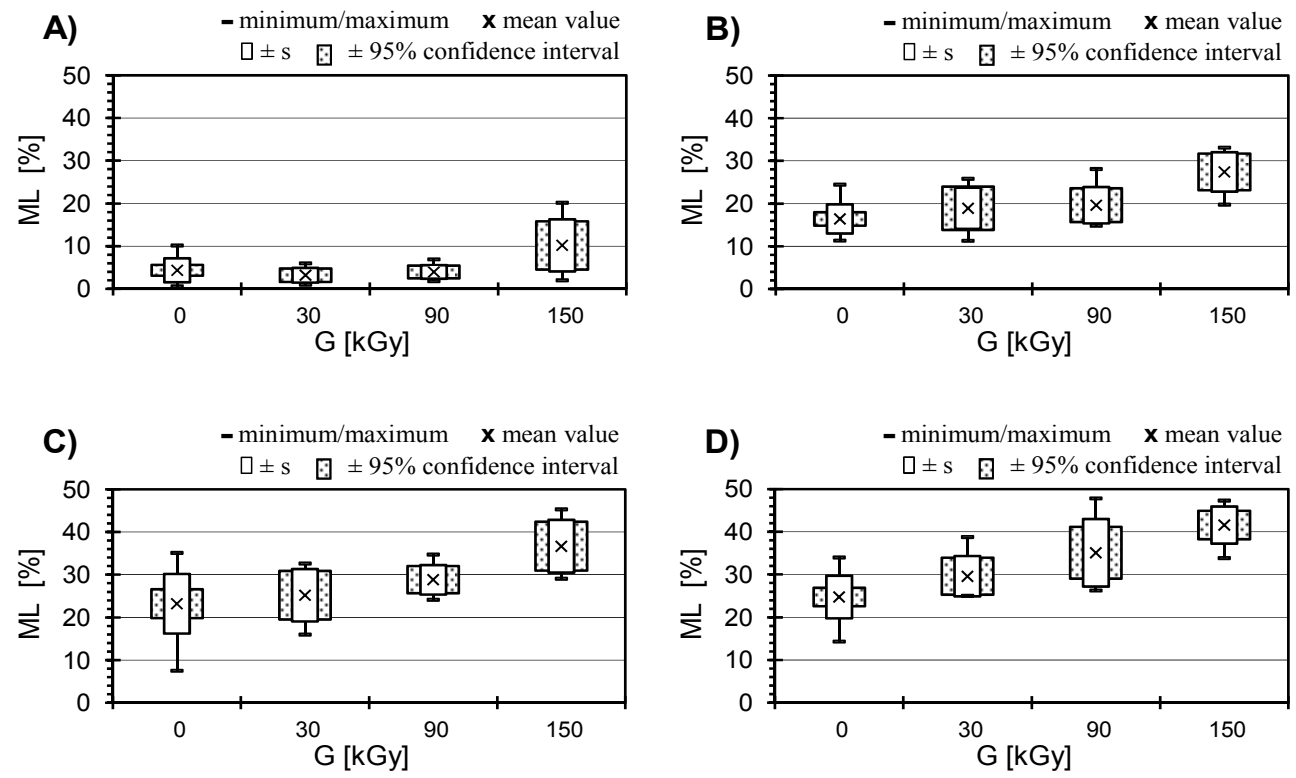

Fig. 16. Mass loss (ML) of autoclaved and irradiated specimens during exposure to fungus Poria placenta: A) 4 weeks incubation; B) 8 weeks incubation; C) 12 weeks incubation; D) 16 weeks incubation; (irradiated specimens $n=7 ; G=0 \mathrm{kGy}$ - autoclaved controls $\mathrm{n}=21$ ). 


\section{Resistance against white-rot fungi}

Considering the patterns and mechanisms of decay of white-rot fungi, in the beginning of decay they utilise simple carbohydrates - the ones incurred by gamma radiation. During further incubation, white rot fungi mainly utilise lignin, and they use radical mechanisms to degrade lignin. Broken (somehow modified) lignin accompanied with radicals incurred in wood by gamma radiation could negatively interfere with these decay patterns. Therefore no significant difference in ML caused by white-rot fungi between autoclaved and irradiated specimens was determined (Despot et al., 2006; Hasan et al. 2006a).

In contrary to white rot, brown rot decay mechanisms, particularly decay mechanism of $P$. placenta, are less radical dependent, higher radiation doses do not influence the decay patterns of this brown rot fungus. In contrast, higher irradiation resulted in higher degree of depolymerisation, what makes wood significantly more susceptible to dacay (Despot et al. 2006, 2007; Figure 17).
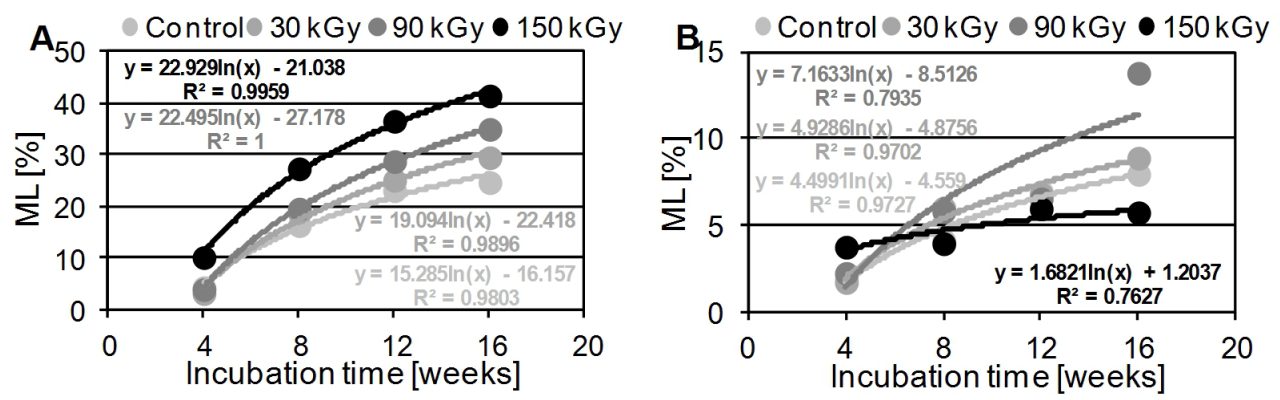

Fig. 17. Correlation between Mass loss (ML) of autoclaved and irradiated specimens and incubation time to fungus: A) Poria placenta; B) Trametes versicolor.

However, it has to be taken into consideration that depolymerisation of wood components by gamma irradiation is one aspect that could explain differences in changed "natural" durability of pine wood and needs to be considered for wood durability testing.

\section{Summary}

Gamma radiation at a level of 30 to $150 \mathrm{kGy}$ causes irreversible and permanent changes in chemical and mechanical properties of wood. Using the HEMI test method it was possible to detect small but significant changes in structural integrity and brittleness of wood caused by gamma radiation. With increasing radiation dose the total amount of water-soluble sugars increased linearly, while the maximum swelling seems to be unchanged.

The method of sterilisation has a considerable influence on the natural durability of pine wood. However, wood sterilisation by gamma radiation has different influence on white 
rot and brown rot causing fungi. Significantly greater mass loss of gamma irradiated wood than autoclaved wood has been established in the beginning of incubation to whiterot fungi. During further incubation, the differences diminished. In contrast, higher irradiation resulted in higher degree of cellulose depolymerisation, what makes wood significantly more susceptible to biodegradation by brown-rot fungi. Degradation of gamma-irradiated wood is greater and faster due to easier accessibility of simpler carbohydrates to fungi.

\section{Acknowledgements}

Part of the research on the influence of gamma radiation onto wood properties was supported by the COST Action E37 in the frame of a Short-Term Scientific Mission (STSM) awarded to Marin Hasan, PhD. Parts of the experimental work were carried out at the Federal Research Centre for Forestry and Forest Products (BFH), Hamburg, Germany, which was the STSM host institution, and whose hosting is gratefully acknowledged. The authors extend their particular thanks to BFH and to Ruđer Bošković Institute in Zagreb, Croatia for gamma radiation provision and to its scientists for sharing their wide-ranging scientific expertise on gamma radiation.

\section{References}

Ardica, S., Calderaro, E., Cappadona, C. (1984) Radiation pretreatments of cellulose materials for the enhancement of enzymatic hydrolysis - II. Wood chips, paper, grain straw, hay, kapok. Instituto di Applicazioni e Impianti Nucleari, University of Palermo, Italy.

Bakraji, E. H, Salman, N, Al-kassiri, H. (2001) Gamma-radiation-induced wood-plastic composites from Syrian tree species. Radiation Physics and Chemistry. 61(3): 137141.

Bakraji, E.H., Salman, N., Othman, I. (2002) Radiation-induced polymerization of acrylamide within Okoume (Aucoumea klaineana pierre). Radiation Physics and Chemistry. 64(4): 277-281.

Bogner, A. (1993) Modifikacija površine bukovine radi poboljšanja lijepljenja. Doktorska disertacija. Šumarski fakultet, Zagreb. pp. 141. (in Croatian language).

Bogner, A., Ljuljka, B., Grbac, I. (1997) Improving the glued joint strength by modifying the beech wood (Fagus sylvatica L.) with gamma rays. Drvna industrija 47(2): 68-73.

Brischke, C., Rapp, A.O., Welzbacher, C.R. (2006a) High-energy multiple impact (HEMI) test - Part 1: A new tool for quality control of thermally modified timber. Document No. IRG/WP 06-20346, International Research Group on Wood Protection, Troms $\emptyset$, Norway.

Brischke, C., Welzbacher, C.R., Rapp, A.O. (2006b) Detection of fungal decay by high-energy multiple impact (HEMI) testing. Holzforschung 60 (2): 217-222.

Brischke, C., Welzbacher, C.R., Huckfeldt, T. (2008) Influence of fungal decay by different basidiomycetes on the structural integrity of Norway spruce wood. Holz als Rohund Werkstoff 66: 433-438. 
Brischke, C., Welzbacher, Huckfeldt, T., Schuh, F. (2009) Impact of decay and blue stain causing fungi on the structural integrity of wood. Document No. IRG/WP/0910699. International Research Group on Wood Protection, Beijing, China.

Brischke, C., Zimmer, K., Ulvcrona, T., Bollmus, S., Welzbacher, C.R., Larsson-Brelid, P.. Thomsen, O. (2012) Structural integrity of differently modified wood. $6^{\text {th }}$ European Conference on Wood Modification, Ljubljana, Slovenia, 17-18 September 2012. In print.

Chawla, J. S. (1985) Degradation of Ligno-Cellulose Biomass, Holzforschung und Holzverwertung 37(2): 101-105.

Csupor, K., Divos, F., Gonczol, E. (2000) Radiation induced effects on wood material and fungi, In: Proceedings of 12th Int. symposium on nondestructive testing of wood, Sopron, 13. - 15. September, 2000.

Curling, S., Winandy, J.E. (2008) Comparison of the effects of gamma irradiation and steam sterilization on southern pine sapwood. Forest Products Journal 58(1/2): 87-90.

Cutter, B.E., McGinnes Jr, E.A., Schmidt, P.W. (1980) X-ray scattering and X-ray diffraction techniques in studies of gamma-irradiated wood. Wood and Fiber Science 11(4): 228-232.

Davis, J. R., Ilic, J., Wells, P. (1993) Moisture content in drying wood using direct scanning gamma-ray densitometry. Wood and Fiber Science 25(2): 153-162.

Despot, R., Hasan, M., Glavaš, M., Rep, G. (2006) On the changes of natural durability of wood sterilised by gamma radiation. Document No. IRG/WP 06-10571, International Research Group on Wood Protection, Tromsø, Norway.

Despot, R., Hasan, M., Brischke, C., Welzbacher, C.R., Rapp, A.O. (2007) Changes in physical, mechanical and chemical properties of wood during sterilisation by gamma radiation. Holzforschung 61(3): 267-271.

Despot, R., Hasan, M., Rapp, A.O., Brishke, C., Welzbacher, C.R. (2008) The Effect of Gamma Radiation on Selected Wood Properties. Document No. IRG/WP 08-40394, International Research Group on Wood Protection, Istanbul, Turkey.

Divos, F., Bejo, L. (2005) The effect of gamma irradiation on the MOE of various species. Wood Science and Technology, 40(2): 87-93.

El-Osta, M.L.M., El-Miligy, A.A., Kandeel, S.E., El-Lakany, M.H., El-Morshedy, M.M. (1985) Mathematical description of the change in properties of Causaria wood upon exposure to gamma radiation. 1. Changes in the compression and tensile strength. Wood and Fiber Science 17(1): 2-10.

European Standard (1996) EN 113. Wood preservatives - Test method for determining the protective effectiveness against wood destroying basidiomycetes - Determination of the toxic values.

Fadel, M. A., Kasim, S. A. (1977) A devised light absorption method for measuring fast neutron fluences and gamma doses in mixed radiation fields using a cellulose acetate detector. Nuclear Instruments \& Methods. 146(3): 513-516.

Fairand, B., Ražem, D. (2010) Radiation sterilization. Chapter in the book:Pharmaceutical Dosage Forms: Parenteral Medications. Third Edition, Vol.2: Facility Design, 
Sterilization and Processing. Ed. Nema, S., Ludwig, J.D. Informa Healthcare USA, Inc. New York, N.Y. 268-296.

Fengel, D., Wegener, G. (1989) Wood, Chemistry, Ultrastructure, Reactions. Reprint - Kessel Verlag, 2003. Germany. pp. 613.

Freitag, C.M., Morrell, J.J. (1998) Use of gamma radiation to eliminate fungi from wood. Oregon State University (OSU). 76-78.

Hasan, M. (2006): New knowledge on the wood sterilisation by gamma radiation. Master Thesis. Faculty of Forestry, University of Zagreb. Zagreb. pp. 120.

Hasan, M., Despot, R., Humar, M., Pohleven, F., Rep, G. (2006a): Contribution to Understanding the Biodegradation Mechanism of Wood Sterilised by Gamma Radiation. International Journal of Medicinal Mushrooms. 9(3-4): 308-309.

Hasan, M., Despot, R., Rapp, A.O., Brischke, C., Welzbacher, C.R. (2006b) Some Physical and Mechanical Properties of Wood Sterilised by Gamma Radiation. International Conference Wood Structure and Properties '06. Zvolen, Slovakia. Arbora Publishers. pp. 239-244.

Hasan, M., Despot, R., Sinković, T., Jambreković, V., Bogner, A., Humar, M. (2008) The influence of sterilisation by gamma radiation on natural durability of wood. Wood Research. 53(4): 23-34.

Huckfeldt, T.; Eichhorn, M.; Koch, G.; Welzbacher, C.R.; Brischke, C. (2010) Bewertung von Schäden an dauerhaften Hölzern am Beispiel von Bongossi (Lophira alata). Europäischer Sanierungskalender 2010: 95-108.

Ifju, G. (1964) Tensile strength behaviour as a function of cellulose in wood. Forest Products Journal 14(8): 366-372.

Karsulovic, J. T., Dinator, M. I., Morales, R. (2002) Nondestructive gamma radiation methods for detection of central rot in loges of lenga (Nothogagus pumilo), Forest Products Journal 52(11/12): 87-93.

Katušin-Ražem, B., Ražem, D., Braun, M. (2009) Irradiation treatment for the protection and conservation of cultural heritage artefacts in Croatia. Radiation Physics and Chemistry. 78(7/8): 729-731.

Kenaga, D.L., Cowling, E.B. (1959) Effect of gamma radiation on ponderosa pine: hygroscopicity, swelling and decay susceptibility. Forest Products Journal 9(3): 112116.

Klimentov, S.A., Bysotskaia, I.F. (1979) Investigation of radiation-destroyed wood. 1. Constants of hydrolysis rate of hard hydrolysable polysaccharides of gammairradiated lingocellulose. Khimiya Drevesiny, Riga 5: 30-32.

Klimentov, S.A., Skvortsov, S.V., Ershov, B.G. (1981) Influence of gamma radiation on the chemical composition of wood hydrolysates. Journal of Applied Chemistry of the USSR. 53(2/7): 1254-1257.

Kunstadt, P. (1998) Radiation disinfestations of wood products. Radiation Physics and Chemistry 52(1-6):617-623.

Lester. P.J., Rogers, D.J., Petry, R.J., Connolly, P.G., Roberts, P.B. (2000) The lethal effects of gamma irradiation on larvae of the Huhu beetle, Prionoplus reticularis: a potential quarantine treatment for New Zealand export pine trees. Entomologia Experimentalis et Applicata. 94(3): 237-242. 
Lhoneux, B. de, Antonie, R., Cote, W.A. (1984) Ultrastructural implications of gammairradiation of wood [Pseudotsuga mensziessi, Liridendron tulipifera], Wood Science and Tecnology. 18(3): 161-176.

Loos, W.E. (1962) Effect of Gamma Radiation on the Toughness of Wood. Forest Products Journal 12(5): 261-264.

Lu, C., Lam, F. (1999) Study on the X-ray calibration and overlap measurements in robot formed flakeboard mats, Wood Science and Technology 33(2): 85-95.

Magaudda, G., Adamo, M., Rocchetti, F. (2001) Damage caused by destructive insects to cellulose previously subjected to gamma-ray irradiation and artificial ageing. Restaurator - International Journal for the Preservation of Library and Archival Material 22(4): 242-250.

Oldham, S.C., Nolan, P.F., Maclenan, M.P. (1990) A gamma-radiographic study of wood and polymer combustion and the effects of flame retardants. Nuclear Instruments and Methods in Physics Research Section A: Accelerators, Spectrometers, Detectors and Associated Equipment. 299(1-3): 661-665.

Panshin, A. J., deZeeuw, C. (1980) Textbook of Wood Technology, Structure, Identification, Properties, and Uses of the Commercial Woods of the United States and Canada, Fourth Edition. McGraw-Hill, Inc., pp: 722.

Pratt, L.H., Smith, D.G., Thornton, R.H., Simmons, J.B., Depta, B.B., Johnson, R.B. (1999) The effectiveness of two sterilisation methods when different precleaning techniques are employed. Journal of Dentistry. 27(3): 247-248.

Rapp, A.O., Sailer, M., Brand, K. (2003) Umweltfreundliche Konservierung von Massivholz und Massivholzprodukten für den Außenbereich. Schlussbericht für das BMBFProjekt 0339862. Bundesforschungsanstalt für Forst- und Holzwirtschaft (BFH), Hamburg.

Rapp, A.O., Brischke, C., Welzbacher, C.R. (2006) Interrelationship between the severity of heat treatments and sieve fractions after impact ball milling: a mechanical test for quality control of thermally modified wood. Holzforschung. 60(1): 6470.

Rapp, A.O., Brischke, C., Welzbacher, C.R., Nilsson, T., Björdal, C. (2008) Mechanical strength of wood from the Vasa shipwreck. Stockholm: The International Research Group on Wood Protection, IRG/WP/08-20381.

Seaman, J.F., Millett, M.A., Lawton, E.J. (1952) Effect of high energy cathode rays on cellulose. Industrial \& Engineering Chemistry Research 44(12): 2848-2852.

Seifert, K. (1964) Zur Chemie gammabestrahlten Holzes. Holz als Roh- und Werkstoff. 22(7): 267-275.

Sheikh, N., Afshar Taromi, F. (1993) Radiation induced polymerization of vinyl monomers and their application for preparation of wood-polymer composites. Radiation Physics and Chemistry. 42(1-3): 179-182.

Sharman, C.V., Smith, R.S. (1970) Gamma radiation sterilization of ponderosa pine and birch sapwood. Wood and Fiber Science 2(2): 134-143.

Shuler, C.E. (1971) Gamma Irradiation Effects On Modulus of Elasticity Of Engelman Spruce. Forest Products Journal 21(1):49-51. 
Shuler, C.E., Shottafer, J.E., Campana, R.J. (1975) Effect of Gamma Irradiation In Vivo On the Flexural Properties of American Elm. Wood Science and Technology 7(3): 209-212.

Šimkovic, I., Mlynár, J., Alföldy, J., Lübke, H., Micko, M.M. (1991) Increased extractability of irradiated wood meal. Holzforschung 45(3): 229-232.

Severiano, L.C., Lahr, FA.R., Bardi, M.A.G., Santos, A.C., Machado, L.D.B. (2010) Influence of gamma radiation on properties of common Brazilian wood species used in artwork. Progress in Nuclear Energy. 52(8): 730-734.

Struszczyk, H., Ciechańska, D., Wawro, D., Niekraszewicz, A., Strobin, G. (2004) Review of alternative methods applying to cellulose and chitosan structure modification. Radiation processing of polysaccharides, International Atomic Energy Agency IAEA. November, 2004. pp. 55-65.

Subrahmanyam, V.S., Das, S.K., Ganguly, B.N., Bhattacharya, A.DeA. (1998) Positron anihilation study on gamma-irradiated cellulose acetate matrix. Polymer. 39(6-7): 1507-1508.

Tabirih, P.K., McGinnes Jr, E.A., Kay, M.A., Harlow. C.A. (1977) A note on anatomical changes of white oak wood upon exposure to gamma radiation. Wood and Fiber Science 9(3): 211-215.

Tišler, V., Medved, S. (1997) Changes in wood structure due to irradiation by gamma rays. Les-Wood 49(4): 85-89. (in Slovenian language).

Tsutomu, A., Misato, N., Tadashi Y. (1977) Some Physical Properties of Wood and Cellulose Irradiated with Gamma Rays. Wood Research. 62(1): 19-28.

Unger, A., Schiewind, A. P., Unger, W. (2001) Conservation of Wood Artifacts, A Handbook. Berkeley and Eberswalde, Berlin. pp. 346-348 and 497-498.

Welzbacher, C.R., Brischke, C., Rapp, A.O. (2006) High-energy multiple impact (HEMI) -test - Part 2: A mechanical test for the detection of fungal decay. Document No. IRG/WP 06-20339, International Research Group on Wood Protection, Tromsø, Norway.

Welzbacher, C.R., Brischke, C., Rapp, A.O. (2007) Influence of treatment temperature and duration on selected biological, mechanical, physical, and optical properties of thermally modified timber (TMT). Wood Material Science and Engineering 2: 6676.

Welzbacher, C.R., Brischke, C., Rapp, A.O. (2009) Estimating the heat treatment intensity through various properties of thermally modified timber (TMT). Document No. IRG/WP/09-40459. International Research Group on Wood Protection, Beijing, China.

Welzbacher, C.R., Rapp, A.O., Haller, P., Wehsener, J. (2004) Thermisch vergütete und verdichtete Fichte für tragende Anwendungen im Ingenieurholzbau. AiF Forschungsbericht 63 ZBR $1 / 2$.

Welzbacher, C.R., Rassam, G., Talaei, A., Brischke, C. (2011) Microstructure, strength and structural integrity of heat-treated beech and spruce wood. Wood Material Science and Engineering 6: 219-227. 
Zamani, M., Savides, E., Charalambous, S. (1981) The response of cellulose nitrate to gamma radiation. Nuclear Tracks \& Radiation Measurements-International Journal of Radiation Applications \& Instrumentation, Part D. 4(3): 171-176. 


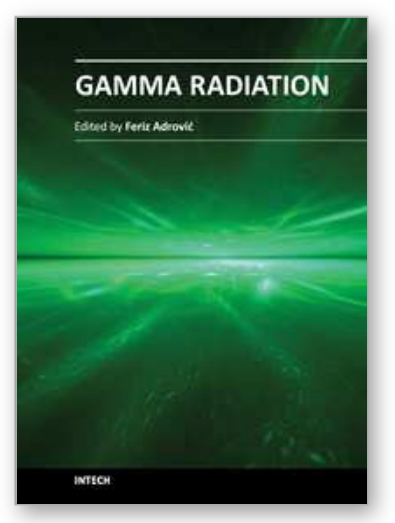

\author{
Gamma Radiation \\ Edited by Prof. Feriz Adrovic
}

ISBN 978-953-51-0316-5

Hard cover, 320 pages

Publisher InTech

Published online 21, March, 2012

Published in print edition March, 2012

This book brings new research insights on the properties and behavior of gamma radiation, studies from a wide range of options of gamma radiation applications in Nuclear Physics, industrial processes, Environmental Science, Radiation Biology, Radiation Chemistry, Agriculture and Forestry, sterilization, food industry, as well as the review of both advantages and problems that are present in these applications. The book is primarily intended for scientific workers who have contacts with gamma radiation, such as staff working in nuclear power plants, manufacturing industries and civil engineers, medical equipment manufacturers, oncologists, radiation therapists, dental professionals, universities and the military, as well as those who intend to enter the world of applications and problems of gamma radiation. Because of the global importance of gamma radiation, the content of this book will be interesting for the wider audience as well.

\title{
How to reference
}

In order to correctly reference this scholarly work, feel free to copy and paste the following:

Radovan Despot, Marin Hasan, Andreas Otto Rapp, Christian Brischke, Miha Humar, Christian Robert Welzbacher and Dušan Ražem (2012). Changes in Selected Properties of Wood Caused by Gamma Radiation, Gamma Radiation, Prof. Feriz Adrovic (Ed.), ISBN: 978-953-51-0316-5, InTech, Available from: http://www.intechopen.com/books/gamma-radiation/changes-in-selected-properties-of-wood-duringsterilisation-by-gamma-radiation

\section{INTECH}

open science | open minds

\author{
InTech Europe \\ University Campus STeP Ri \\ Slavka Krautzeka 83/A \\ 51000 Rijeka, Croatia \\ Phone: +385 (51) 770447 \\ Fax: +385 (51) 686166 \\ www.intechopen.com
}

\author{
InTech China \\ Unit 405, Office Block, Hotel Equatorial Shanghai \\ No.65, Yan An Road (West), Shanghai, 200040, China \\ 中国上海市延安西路65号上海国际贵都大饭店办公楼405单元 \\ Phone: +86-21-62489820 \\ Fax: +86-21-62489821
}


(C) 2012 The Author(s). Licensee IntechOpen. This is an open access article distributed under the terms of the Creative Commons Attribution 3.0 License, which permits unrestricted use, distribution, and reproduction in any medium, provided the original work is properly cited. 